\title{
Opinions of Future Primary Education Teachers on the Application of Drama in Education (DiE)
}

\author{
Zrinka Vukojević \\ University of Zagreb, Faculty of Teacher Education
}

\section{Abstract}

The paper presents the results of the research which examined the relationship between the sense of competence of future primary education teachers for DiE and their opinions on the importance of applying DiE in teaching. The research was carried out on a sample of $N=225$ students. The participants were students of the Faculty of Teacher Education in Zagreb (N=95) with the Čakovec branch $(N=69)$ and Petrinja branch $(\mathrm{N}=26)$ as well as students of the Faculty of Humanities and Social Sciences in Split - Department of Teacher Education (N=35). Research results show that students have an affinity for DiE although only 15\% of the participants consider themselves competent for applying DiE.

Key words: competences; Drama in Education; students in primary education program of study.

\section{Introduction}

Theoretical considerations indicate that art is a subject of interest for many scientists and professionals who deal with enhancing the process of education. Art is usually observed as a means for promoting pupils' creativity. Art helps pupils develop the ability to take initiative, develop emotional intelligence, imagination and critical and analytical thinking. Art education and its content influence the entire development of an individual, contribute to their better functioning in the contemporary world and prepare them for the future, which demands flexibility, fast decision-making and problem-solving (Turković, 1999). According to Alter, Hays, and O'Hara (2009), primary education teachers are indispensable teachers of subjects which include knowledge from the areas of psychology, pedagogy, philosophy, literature, linguistics, 
information sciences and natural sciences. A specific part of the profession assumes acquiring knowledge and skills from the field of artistic expression. All of that presents great responsibility of the teacher, and is related to quality of teaching and teacher's self-confidence and competences in the teaching process. According to research by $\mathrm{Ng}$, Nicholas, and Williams (2010), teachers possess various knowledge, experiences and skills necessary for teaching different subjects. Jacobs (2008) emphasized how, due to lack of knowledge, experience and self-confidence in the field of art, teachers frequently create a negative attitude towards the arts, which is reflected in the implementation of art content when working with pupils. The quality and quantity of teaching art content is manifested in the educational background and self-confidence of future primary education teachers. Considering the fact that quality planning and implementation of teaching, which includes the field of art, depends on the teacher, the aim of this research was to examine the opinions of future primary education teachers on the application of DiE in teaching.

\section{The Importance of Drama in Education}

Dramatic art was introduced for the first time into the Croatian National Curriculum Framework for preschool education and general compulsory and high school education as a separate art field (NOK, 2011). Research has shown that dramatic art influences the development of a child's linguistic skills and empathy (Adomat, 2012; Anderson, 2012; Barnes, 2014; Holland, 2009), and increases the pupils' motivation for and engagement in learning (Martin et al., 2013). In the Croatian curriculum, the learning outcomes clearly show the effort to recognize drama education within school and subject curricula not only as content of particular subjects (e.g. literature), but as a teaching method and form of experiential learning and teaching applicable in various educational areas and for various educational topics (Krušić, 2014). Over the last ten years, a vast body of research (Drama Improves Lisbon Key Competences in Education Consortium, 2011; Mclauchlan \& Winters, 2014; Villadsen, 2012; Walker et al., 2011; Wright, 2006) points to the importance of integrating drama into the system of education. In Anglo-Saxon countries, drama is used as a modern method of learning and teaching. It is most frequently defined as a teaching method used for creating a fictive environment with the aim for the individual to take on a role and develop his/her experience, knowledge, feelings and skills (Ekeberg, Lepp, \& Dahlberg, 2004; San, 1998; Sternberg, 1998). Although Croatian educational policy recognizes educational, cultural and social advantages of dramatic arts in the education process, its implementation has insufficiently penetrated daily educational work. The reason behind it is that teachers tend to marginalize subjects which they are not inclined to and for which they do not possess sufficient knowledge and skills (Alter, Hays, \& O'Hara, 2009). Recent theoretical considerations call for changes in pre-service teacher education. It is emphasized that teachers should be innovators in their work, and in order to realize that, it is necessary to implement creative and imaginative methods 
which will make their teaching interesting, relevant and attractive. The use of such methods and approaches in teaching will satisfy a child's need for play, imagination and creation. The implementation of drama in educational work with pupils presents an interpretative process with the aim to understand reality better (Laakso, 2005). According to Duma \& Silverstein (2008), DiE encourages motivation, develops multiple intelligences and encourages various learning styles. The position of the teacher and the pupil in such forms of work enables the pupil to freely express feelings, thoughts and attitudes, and express their decision-making skills (McNaughton, 2006). In that way, the teacher's authoritative mask is lost and interaction is encouraged aiming for discussion and negotiation with pupils and their active involvement in the education process (Upitis et al., 2001). At first, teachers were reluctant to apply drama as a teaching method as they felt they lacked knowledge (Fynn, 1997), or because of time constraints (Stinson, 2009). However, with drama experience, knowledge and skills, they began implementing creativity in a more efficient way, and started applying drama in school subjects for various educational purposes (Oreck, 2006). Using appropriate drama methods, teachers are able to face problems and issues in their professional work, become aware of the poetic-aesthetic dimension of the dramatic arts (Kerry-Moran \& Meyer, 2009), develop vocabulary, enhance their teaching methods and acquire knowledge from various areas. Research has shown that by implementing drama in the teaching process, teachers become representatives of educational change (Ryan, 2005). By offering support, motivation, professionalism, knowledge and skills in such forms of work (Oreck, 2006) they provide their pupils with quality life practice (Raphael \& O'Mara, 2002). According to Waldschmidt (1998), teachers emphasize that the integration of drama in teaching could not be possible without learning from their own real experiences and without having previously acquired knowledge.

\section{Drama in Education at Higher Education Institutions}

The profile of a teacher being educated at higher education institutions is based on quality pedagogical and psychological teaching methodology and professional education, which will contribute to the creativity, resourcefulness and flexibility of the teaching process. Study programs at faculties of teacher education should provide students with the knowledge, skills and experiences essential for their successful work in the future. Recent research based on theory and practice of the integration of dramatic arts in teaching proves that drama promotes the development of creative and intellectual abilities of a child. In the research by Lummis et al. (2015), opinions and experiences of future teachers relating to $\mathrm{DiE}$ were examined. The research results showed that those students who engaged in drama workshops during their childhood or during primary education, i.e. those who went to theaters and who were taught by drama methods, exhibit a greater affinity for DiE and consequently emphasize its importance in the education process. In the research by Russell-Bowie et al. (1995) it was shown that if primary education students have greater background knowledge of 
DiE, and have been involved in drama activities throughout their higher education, it significantly contributes to their confidence and competence in DiE teaching methods and techniques. According to Russell-Bowie (2010), greater emphasis placed on the development of knowledge, competences, opinions and skills gained from $\mathrm{DiE}$ will result in a greater student competence, and at the same time they will acquire an affinity for DiE. Akin (2014) pointed out that future teachers show a great affinity for DiE as they consider that its implementation in teaching will make working with pupils easier and make lessons more interesting and fun. On the other hand, according to Wright (1999), most primary school pupils who attended these DiE classes experience stage fright when they have to perform in these activities. Alter et al. (2009) emphasize that this type of fear has a great impact on the competence and successfulness of teaching dramatic art in these subjects. It has also been shown that the students who seemed to have the greatest fear of performing agreed that dramatic art should be taught by an experienced teacher in that field, not a standard primary school teacher. In line with the mentioned research, the aim of this research was to examine the opinions of future primary school teachers in the cities of Zagreb, Split, Čakovec and Petrinja. These opinions were based on their competence and affinity for $\mathrm{DiE}$ in the teaching process.

\section{Methodology}

\section{Research Aims, Problems and Hypotheses}

The aim of the research was to examine the relationship between future primary teachers' self-evaluation of competences related to $\mathrm{DiE}$, their opinions on the importance of applying DiE in teaching and the teacher's affinity for DiE. The starting point is the general idea that those students who consider themselves competent express their opinion that the application of $\mathrm{DiE}$ in teaching is important and that teachers like to apply DiE. In addition, they will be more prone to thinking that they, and not specialized drama art teachers, should apply DiE. In relation to these formulated aims, the following objectives and hypotheses were set:

1. To construct a questionnaire for the self-evaluation of competence in DiE among future primary education teachers.

2. To examine the correlation between the self-evaluations of competence and the opinions on applying DiE in teaching.

3. To examine the correlation between self-evaluations of competence and opinion regarding teachers' affinity for applying DiE.

4. To examine the differences in the self-evaluations of competence between students who think that $\mathrm{DiE}$ should be applied by specialized teachers, primary education teachers or by both primary and specialized teachers equally.

H2.1. A positive correlation between the self-evaluation of competence and the estimation of the importance of applying $\mathrm{DiE}$ is expected.

H3.1. A positive correlation between the self-evaluation of competence and students' opinion that teachers like to apply $\mathrm{DiE}$ is expected. 
H4.1. It is expected that students who think that DiE should be applied by primary education teachers will evaluate themselves as more competent in $\mathrm{DiE}$ than students who think that specialized teachers or both primary and specialized teachers equally should apply DiE.

\section{Sample of Participants}

The research was carried out in November during the 2016/2017 academic year. The questionnaire was distributed to a sample of 225 students. The participants were fifth-year students of primary teacher education at the Faculty of Teacher Education in Zagreb $(\mathrm{N}=95)$, in Čakovec $(\mathrm{N}=69)$ and Petrinja $(\mathrm{N}=26)$, and students at the Faculty of Humanities and Social Sciences in Split - Department of Teacher Education $(\mathrm{N}=$ 35). The participants were informed about the purpose of this research. They were guaranteed anonymity and were asked to provide honest answers. The participants could withdraw from participation in the research at any time.

\section{Instruments}

This research is part of a large-scale research which used a questionnaire to learn about the attitudes of future primary education teachers towards the creative arts (Creative Arts: Students'Attitudes: National and Overseas Associates (CASANOVA), according to Russell-Bowie, 2013).

Statements relevant to the issues of this particular research were selected from the mentioned questionnaire. Based on the statements, two questionnaires were constructed: a questionnaire for the self-evaluation of competence in $\mathrm{DiE}$ and a questionnaire for examining opinions on the importance of $\mathrm{DiE}$ in teaching.

\section{Self-evaluation of Competence in DiE}

Statements selected from the previously mentioned questionnaire were related to the experience of participants in $\mathrm{DiE}$ (In my free time, I participate in DiE), knowledge and skills in the area of $\mathrm{DiE}$ (I believe that I possess knowledge and competence related to $\mathrm{DiE}$ ), an affinity for $\mathrm{DiE}$ (I would like it if there were more elective courses in the area of DiE), and stage fright when performing in DiE (I'm embarrassed when I have to perform in front of pupils). The initial questionnaire had 22 statements that referred to different characteristics of future teachers important for the application of $\mathrm{DiE}$ in teaching. After the factor analysis was performed, 18 statements were retained. The participants evaluated each statement on a five-point scale (1 - I strongly disagree to 5 - I strongly agree). The factor structure of the questionnaire is shown in the part relating to the research results.

\section{Opinion on the Importance of Applying DiE in Teaching}

Four statements that referred to students' opinions on the importance of DiE in school were selected from the above-mentioned questionnaire:

More importance should be given to drama work in primary education teaching.

I think that DiE is insufficiently represented in primary education. 
Pupils need to be educated by drama methods and techniques.

$D i E$ is as important as other subjects in primary education.

The participants evaluated each statement on a five-point scale (1 - I strongly disagree to 5 - I strongly agree). The factor analysis using the method of principal components resulted in one factor which explained $48.66 \%$ of the variance. The Cronbach's alpha coefficient of reliability was .71, which is an acceptable value. The total result is defined as an average result for the mentioned statements. The greater result indicates that teachers assign more importance to DiE in primary school.

\section{Teachers' Willingness for Applying DiE}

The evaluation of teachers' willingness to apply DiE was measured using one statement: I think that primary education teachers like to apply DiE. The participants evaluated the statement on a five-point scale ( 1 - I strongly disagree to 5 - I strongly agree).

\section{Opinion about Who Should Apply DiE in Primary Education}

The participants evaluated two statements on a five-point scale (1 - I strongly disagree to 5 - I strongly agree).

Specialized teachers should be applying DiE in primary school education

Primary education teachers should be applying DiE in primary education.

Based on the evaluations, the participants were divided into three groups: those who gave priority to primary school teachers, those who gave priority to specialized teachers and those who evaluated that both primary and specialized teachers can apply DiE equally.

\section{Data Analysis and Statistical Methods}

An exploratory factor analysis with the method of principal components was applied to test the factor structure of the questionnaire. Regression analyses were carried out to determine the correlation between the self-evaluation of competence in applying $\mathrm{DiE}$ in teaching and teachers' willingness for applying DiE in teaching. Finally, one-way analysis of variance was applied to test differences in the self-evaluation of competence between the three groups of students who had differing opinions on who should be applying DiE in primary school.

\section{Results and Discussion}

\section{Verification of Construct Validity of the Questionnaire for the Self-Evaluation of Competence in DiE among Future Primary Education Teachers}

In order to check the factor structure, an exploratory factor analysis was carried out using the principal components method. The initial factor analysis with 21 statements resulted in five factors, which explained $64.791 \%$ of the total variance. As factor content was not meaningfully interpretative, the factor analysis was repeated using the Scree test with oblimin rotation on three factors. Four statements interfered with the factor structure because of low factor loading (lower than .30) and/or factor loading 
on several factors. Upon removing the four statements (In my leisure time I participate in DiE; Members of my family are involved in DiE; In primary and secondary school I attended extracurricular activities in DiE and I think that it is necessary to be an actor/ actress in order to be competent to teach $\mathrm{DiE}$ ), the factor analysis was repeated using the method of principal components with oblimin rotation on 17 items. The KaiserMeyer-Olkin test $(\mathrm{KMO}=.847)$ and Bartlett's test of sphericity $\left(\chi^{2}=1510.691 ; \mathrm{p}=.000\right)$ established that the data were appropriate for factorization. The obtained three-factor structure was interpretative, and the three factors together explained $51.687 \%$ of the total variance (Table 1). The first factor can be named Knowledge and Skills in DiE Factor and explains $31.672 \%$ of the variance. The second factor can be named Affinity for DiE Factor and upon rotation explains $11.641 \%$ of the variance. The third factor is named Stage Fright Factor and explains $8.375 \%$ of the variance.

Table 1

The factorial structure of the questionnaire for the self-evaluation of competence in DiE and the associated Cronbach's alpha subscale coefficients $(\mathrm{N}=225)$

\begin{tabular}{|c|c|c|c|}
\hline \multirow[b]{2}{*}{ Statements } & \multicolumn{2}{|c|}{ Components } & \multirow[b]{2}{*}{$\begin{array}{l}\text { Stage } \\
\text { fright }\end{array}$} \\
\hline & $\begin{array}{l}\text { Knowledge } \\
\text { and skills }\end{array}$ & Affinity & \\
\hline I think that I possess the knowledge and competences in DiE. & .783 & & \\
\hline $\begin{array}{l}\text { I understand the National teaching curriculum and the National } \\
\text { Curriculum Framework relating to the area of dramatic arts. }\end{array}$ & .679 & & \\
\hline $\begin{array}{l}\text { From the lectures attended in college, I have learned a lot about } \\
\text { drama work with children. }\end{array}$ & .658 & & \\
\hline I have good ideas for DiE. & .617 & & \\
\hline My favorite subject in primary school was Croatian language. & .593 & & \\
\hline $\begin{array}{l}\text { I taught successful individual and public lessons in the area of } \\
\text { Croatian language (literacy and media culture). }\end{array}$ & .563 & & \\
\hline I am confident when I teach literacy and media culture. & .518 & & \\
\hline My favorite subject in high school was Croatian language. & .504 & & \\
\hline I feel inept at DiE courses. & .494 & & \\
\hline I would like it if there were more courses in the area of DiE. & & .792 & \\
\hline If I invested more time, I would be good at acting. & & .763 & \\
\hline If I could, I would be an actor/actress. & & .690 & \\
\hline $\begin{array}{l}\text { I find that more teaching methodology is necessary in the area } \\
\text { of DiE. }\end{array}$ & & .629 & \\
\hline $\begin{array}{l}\text { I think that I acquire knowledge and learn better in courses in } \\
\text { the area of DiE. }\end{array}$ & & .602 & \\
\hline I'm not interested in acting. & & .479 & \\
\hline I'm embarrassed when I have to act in front of pupils. & & & .830 \\
\hline I'm embarrassed when I have to act in front of teachers. & & & .828 \\
\hline I'd feel embarrassed if had to act in front of an audience. & & & .689 \\
\hline$\%$ explained variance & $30.672 \%$ & 11.641 & 8.375 \\
\hline Cronbach's alpha coefficients & .807 & .790 & .809 \\
\hline
\end{tabular}


The Cronbach's alpha coefficient of reliability of the subscale Knowledge and Skills in $D i E$, composed of nine statements, is .807; of the subscale Affinity for DiE, composed of five statements, it is .790, and of the subscale Stage Fright, composed of three statements, it is .809. These are acceptable values.

Statements I feel inept in courses in the area of DiE and I am not interested in acting have been recoded. The overall result on each subscale is defined as the average result on statements that make up the subscale. The higher score on the subscale Knowledge and Skills reflects the better self-evaluation of knowledge and skills in DiE, while the higher score on the scale Affinity for DiE reflects a greater affinity for that art. Higher scores on the subscale Stage Fright indicate a feeling of great discomfort while performing DiE in front of others.

\section{Descriptive Indicators}

Values, asymmetry and kurtosis were calculated for all of the variables. Values for asymmetry ranged from -.048 to -.728 , and for kurtosis from -.435 to -.948, which justifies the use of parametric statistical procedures.

Table 2

Descriptive indicators, correlations and coefficients of internal reliability for the measured variables $(N=225)$

\begin{tabular}{|c|c|c|c|c|c|}
\hline \multicolumn{6}{|c|}{ Correlation coefficients } \\
\hline & 1. & 2. & 3. & 4. & 5. \\
\hline 1. Competence -knowledge and skills & - & $.41^{* *}$ & $-.42^{* *}$ & $.26^{* *}$ & $.41^{* *}$ \\
\hline 2. Competence-affinity & & - & $-.44^{* *}$ & $.46^{* *}$ & $.34^{* *}$ \\
\hline 3. Competence -stage fright & & & - & $-.25^{* *}$ & $-.27^{* *}$ \\
\hline 4. Importance of DiE & & & & - & $.23^{* *}$ \\
\hline 5. Teacher willingness to apply $\mathrm{DiE}$ & & & & & - \\
\hline \multicolumn{6}{|c|}{ Descriptive indicators } \\
\hline Average value & 3.26 & 3.67 & 2.78 & 4.22 & 3.68 \\
\hline Standard deviation & 0.77 & 0.88 & 1.16 & 0.61 & 1.06 \\
\hline Cronbach's alpha & .81 & .79 & .81 & .71 & n.p \\
\hline Actual range & $1.44-5.00$ & $1.40-5.00$ & $1.00-5.00$ & $1.75-5.00$ & $1-5$ \\
\hline Expected range & $1-5$ & $1-5$ & $1-5$ & $1-5$ & $1-5$ \\
\hline
\end{tabular}

The highest evaluation was given by participants to their affinity for $\mathrm{DiE}(\mathrm{M}=3.67$, $\mathrm{SD}=0.88$ ), followed by the evaluation of knowledge and skills for applying $\mathrm{DiE}$ $(\mathrm{M}=3.26, \mathrm{SD}=0.77)$. Both evaluations were slightly above average. Regarding stage fright, students showed a somewhat above average result $(\mathrm{M}=2.78 ; \mathrm{SD}=2.78)$. Furthermore, they gave an above average importance to $\mathrm{DiE}$ in teaching $(\mathrm{M}=4.22$; $\mathrm{SD}=0.61$ ), and a somewhat above average evaluation that teachers like to apply $\mathrm{DiE}$ $(\mathrm{M}=3.68 ; \mathrm{SD}=1.06)$.

Correlations between the tested variables were as had been expected. The correlation between self-evaluation of knowledge and skills and affinity for applying $\mathrm{DiE}$ is 
positive ( $\mathrm{r}=.41)$, while both correlations of these dimensions with a subscale of stage fright are negative ( $r=-.42$ and $r=-.44)$. Furthermore, the self-evaluations of knowledge and skills and affinity for $\mathrm{DiE}$ are in a positive correlation with the evaluations of the importance of $\mathrm{DiE}$ ( $\mathrm{r}=.26$ and $\mathrm{r}=.46$ ) and the evaluation of teachers' willingness to apply $\mathrm{DiE}(\mathrm{r}=.41$ and $\mathrm{r}=.34)$. Contrary to that, stage fright had a negative correlation with those variables ( $\mathrm{r}=-.25$ and $\mathrm{r}=-.27)$.

The research results show that future primary education teachers are inclined towards DiE. Referring to the self-evaluation of knowledge and skills, $15 \%$ of the participants evaluated themselves with a 4 , meaning that they mostly or entirely agree that they are competent for applying DiE. Stage fright did not emerge as a significant predictor for neither of the criterion variables.

\section{Correlation Between Self-Evaluation of Competences and Opinion on the Importance of Applying DiE in Teaching and Affinity of Teachers for Applying DiE}

For determining the correlation between self-evaluations of competence and the importance of applying DiE in teaching, two regression analyses were carried out, for each criterion independently (Table 3 ).

\begin{tabular}{|c|c|c|}
\hline Predictors & $\begin{array}{l}\text { Importance } \\
\text { of DiE }\end{array}$ & $\begin{array}{l}\text { Affinity of teachers } \\
\text { for applying DiE }\end{array}$ \\
\hline & $\beta$ & $\beta$ \\
\hline Knowledge and skills of DiE & .05 & $.31 * * *$ \\
\hline Affinity for DiE & $.52^{* * *}$ & $.20^{* *}$ \\
\hline Stage fright & -.01 & -.06 \\
\hline $\mathrm{R}$ & $.55^{* * *}$ & $.46^{* * *}$ \\
\hline Corrected $\mathrm{R}^{2}$ & $.30 * * *$ & $.20^{* * *}$ \\
\hline
\end{tabular}

The regression analyses showed that an affinity for $\mathrm{DiE}$ is the only significant predictor of importance which students give to $\mathrm{DiE}$ in teaching $(\beta=.52)$. The more affinity students have for $\mathrm{DiE}$, according to their own evaluation, the more they emphasize its importance in teaching. Based on students' opinions on the extent to which primary education teachers like to apply DiE, significant predictors are knowledge and skills in the area of $\operatorname{DiE}(\beta=.31)$, and an affinity for $\operatorname{DiE}(\beta=.20)$. The more knowledge and skills students have in the area of DiE, according to their own evaluations, the more affinity they have for $\mathrm{DiE}$ and believe that teachers like to apply DiE. Stage fright did not emerge as a significant predictor for neither of the criterion variables. The results of this research show that future primary education teachers who have been introduced to drama art at some point in their lives have a greater affinity for applying DiE in their classrooms, and thus will emphasize its meaningfulness in 
the teaching process. The knowledge and skills acquired in drama education are the most significant predictors in attitudes among primary school teachers who enjoy applying $\mathrm{DiE}$ in their classroom. However, an affinity for $\mathrm{DiE}$ is a less significant predictor. These results partially confirm the first two hypotheses.

\section{Self-Evaluations of Competence and Opinion on Who Should Apply DiE}

Students' opinions on who should be applying methods and activities in the area of DiE were also examined. The participants were divided into three groups. The first group is made up of participants who give priority to primary education teachers $(\mathrm{N}=65 ; 28.1 \%)$; the second group is made up of participants who believe that specialized teachers should be applying $\mathrm{DiE}(\mathrm{N}=79 ; 35.1 \%)$, while the third group of participants is made up of those who believe that both specialized and primary teachers can apply $\mathrm{DiE}(\mathrm{N}=81 ; 36 \%)$. In order to test the differences in selfevaluations of competences between the three groups of students, three one-way analyses of variance were carried out (Table 4). Prior to carrying out the analyses, the homogeneity of variance was tested using Levene's test which confirmed the homogeneity of variances.

Table 4

Differences in self-evaluations of competences for DiE depending on the opinion on who should apply DiE in primary education

\begin{tabular}{lccccccccc}
\hline & \multicolumn{2}{c}{$\begin{array}{c}\text { Primary education } \\
\text { teachers }\end{array}$} & \multicolumn{2}{c}{ Spec. teachers } & \multicolumn{2}{c}{ Both } & & \multirow{2}{*}{$\mathrm{F}_{(2 / 222)}$} & $\mathrm{p}$ \\
\cline { 2 - 7 } & $\mathrm{M}$ & $\mathrm{SD}$ & $\mathrm{M}$ & $\mathrm{SD}$ & $\mathrm{M}$ & $\mathrm{SD}$ & & \\
\hline Knowledge and skills & 3.48 & 0.72 & 2.92 & 0.75 & 3.38 & 0.74 & 12.884 & .000 \\
Affinity & 3.79 & 0.87 & 3.47 & 0.93 & 3.84 & 0.79 & 3.684 & .027 \\
Stage fright & 2.41 & 1.10 & 3.05 & 1.14 & 2.90 & 1.13 & 6.973 & .001 \\
\hline
\end{tabular}

All three F ratios were significant, which means that the three groups of students differ significantly according to their results on all three subscales of self-evaluations of competence. Subsequent testing of differences between arithmetic means using the Tukey test showed that, as far as self-evaluations of knowledge and skills are concerned, the students who think that DiE should be applied by specialized teachers evaluate their own knowledge and skills significantly lower than the students who think that $\mathrm{DiE}$ should be applied by primary school teachers $(\mathrm{p}=.001)$, or by both primary education and specialized teachers equally $(\mathrm{p}=.000)$. When referring to the self-evaluations of an affinity for $\mathrm{DiE}$, the students who think that $\mathrm{DiE}$ should be applied by specialized teachers evaluate their affinity significantly lower than the students who think that DiE should be applied by both types of teachers ( $\mathrm{p}=.027)$. The students who think that $\mathrm{DiE}$ should be applied by primary education teachers have significantly lower self-evaluations of stage fright than the students who think that $\mathrm{DiE}$ should be applied by specialized teachers $(\mathrm{p}=.001)$ or by both types of 
teachers ( $\mathrm{p}=.026)$. Therefore, the students - future teachers who evaluate themselves as competent in $\mathrm{DiE}$, are more prone to thinking that $\mathrm{DiE}$ should be applied by primary education teachers, i.e. themselves, once they graduate and start working. The results show that future primary school teachers who consider themselves as having less knowledge and skills for teaching drama education think that $\mathrm{DiE}$ should be applied by specialized teachers. An affinity for $\mathrm{DiE}$ is a significant predictor of the belief that $\mathrm{DiE}$ should be applied by both types of teachers. On the other hand, those future teachers who have a lower affinity towards DiE in the classroom think that it should be exclusively applied by specialized teachers. The results of the research, according to Wright (1999), indicate that future teachers who have a higher level of stage fright feel that specialized teachers should apply DiE. However, those future teachers with a lower level of stage fright feel that both types of teachers can and should apply DiE. Based on these data, it can be concluded that the acquired knowledge, the appropriate skills and an affinity for DiE greatly contribute to the estimation that both types of teachers are necessary for applying DiE in primary classroom.

\section{Conclusion}

The results of this research have shown that future primary teachers have an affinity towards DiE, which proves their awareness of the advantages of applying DiE in the classroom. However, only $15 \%$ of the surveyed students feel that they are competent enough to apply DiE. Moreover, the results show that those future teachers who have experienced various styles of performance art throughout their student education show a greater affinity towards applying DiE, and thus emphasize the importance of its implementation in the teaching process. Future primary school teachers believe that the acquired knowledge and the appropriate skills are the reason why applying $\mathrm{DiE}$ is encouraged by primary school teachers. More so, an affinity for $\mathrm{DiE}$ has been shown as a predictor, but to a lower extent. This is also an indicator of the necessity of developing these abilities and skills in order for future teachers to implement their $\mathrm{DiE}$ knowledge in their work in the classroom one day. Moreover, results show that those students who feel that they have the knowledge, skills and an affinity for DiE, think that both primary school teachers and specialized teachers should be applying $\mathrm{DiE}$. On the other hand, those students who have a lower competence level and an affinity for drama, feel that only specialized teachers are capable of applying DiE methods. On the basis of research analysis, and in the light of acquiring the appropriate competences for implementing $\mathrm{DiE}$ in the teaching process, we have come to the conclusion that there is a need to analyze, question and define key competences which students gain during their study at teacher education institutions, which in turn will help them organize and execute DiE in their teaching lessons more efficiently. 


\section{References}

Adomat, D. S. (2012). Becoming characters: Deepening young children's literary understanding through drama. Journal of Children's Literature, 38, 44-51.

Akin, S. (2014). Review of Research on Drama in Turkish Schools and Pre-service Teacher Education. Elementary Education Online, 13(2), 468-480.

Alter, F., Hays, T., \& O’Hara, R. (2009). Creative arts teaching and practice: Critical reflections of primary school teachers in Australia. International Journal of Education \& the Arts, 10, $1-22$.

Anderson, A. (2012). The influence of process drama on elementary students' written language. Urban Education, 47, 959-982. https://doi.org/10.1177/0042085912446165

Barnes, J. (2014). Drama to promote social and personal well-being in six- and seven-yearolds with communication difficulties. Perspectives in Public Health, 134, 101-109. https:// doi.org/10.1177/1757913912469486

DICE (2011). Drama Improves Lisbon Key Competences in Education Consortium. Retrieved from http:// dramanetwork.eu/

Duma, A. L., \& Silverstein, L. B. (2008). Achieving a greater impact: developing the skills of teaching artists to lead professional development for teachers. Teaching Artist Journal, 6(2), 118-125. https://doi.org/10.1080/15411790801910727

Ekeberg, M., Lepp, M., \& Dahlberg, K. (2004). Reflective learning with drama in nursing education- a Swedish attempt to overcome the theory praxis gap. Nurse Education Today, 24, 622-628. https://doi.org/10.1016/j.nedt.2004.07.011

Flynn, R. M. (1997). Developing and using curriculum-based creative drama in fifth grade reading/language arts instruction: a drama specialist and a classroom teacher collaborate. Youth Theatre Journal, 11(1), 47-69. https://doi.org/10.1080/08929092.1997.10012483

Friedman, L. T. (2013). Need a job? Invent it. The New York Times. Retrieved from http:// www.nytimes.com/2013/03/31/opinion/sunday/friedman-need-a-job-invent-it.html

Holland, C. (2009). Reading and acting in the world: Conversations about empathy. Research in Drama Education, 14, 529-544. https://doi.org/10.1080/13569780903286030

Jacobs, R. (2008). When do we do Macarena?: Habitus and arts learning in primary preservice education courses. International Journal of Pedagogies and Learning, 4, 58-73. https://doi.org/10.5172/ijpl.4.5.58

Kerry-Moran, K. J., \& Meyer, J. M. (2009). Lighting the fires within: pre-service teachers learning in and through drama. In M. J. Narey (Ed.), Making Meaning (pp. 207-228). New York, NY: Springer. https://doi.org/10.1007/978-0-387-87539-2 12

Krušić, V. (2014). Grmljavina iza brda. Retrieved from http://www.hcdo.hr/?page id=1499

Laakso, E. (2005). Encountering drama experiences. The learning potential of process drama in the light of student teachers' experiences. Research in Drama Education: The Journal of Applied Theatre and Performance, 10(3), 355-356. https://doi. org/10.1080/13569780500315398

Lummis, G. E., Morris, J. E., \& Lovering, C. (2015). Exploring the drama experiences of Western Australian pre-service primary teachers. Drama Australia Journal, 39(1), 19-30. https://doi.org/10.1080/14452294.2015.1083515 
Martin, A. J., Mansour, M., Anderson, M., Gibson, R., Liem, G. A. D., \& Sudmalis, D. (2013). The role of arts participation in students' academic and nonacademic outcomes: A longitudinal study of school, home and community factors. Journal of Educational Psychology, 105, 709-727. https://doi.org/10.1037/a0032795

McLauchlan, D., \& Winters, K. L. (2014). What's so great about drama class? Year I secondary students have their say. Research in Drama Education: The Journal of Applied Theatre and Performance, 19(1), 51-63. https://doi.org/10.1080/13569783.2013.872431

McNaughton, M. J. (2006). Learning from participants' responses in educational drama in the teaching of education for sustainable development. Research in Drama Education, 11, 19-41. https://doi.org/10.1080/13569780500437572

Nacionalni okvirni kurikulum za rani i predškolski odgoj i obrazovanje. (2011). Zagreb: Ministarstvo znanosti, obrazovanja i športa.

Ng, W., Nicholas, H., \& Williams, A. (2010). School experiences on pre-service teachers' evolving beliefs about effective teaching. Teaching and Teacher Education, 26, 278-289. https://doi.org/10.1016/j.tate.2009.03.010

Oreck, B. (2006). Artistic choices: a study of teachers who use arts in the classroom. International Journal of Education and the Arts, 7(8), 1-26.

Raphael, J., \& O’Mara, J. (2002). A challenge, a threat and a promise: drama as professional development for teacher educators. Melbourne Studies in Education, 43(2), 77-86. https:// doi.org/10.1080/17508480209556404

Russell-Bowie, D. (2010). Cross-national comparison of background and confidence in visual arts and music education of pre-service primary teachers. Australian Journal of Teacher Education, 35, 76-86. https://doi.org/10.14221/ajte.2010v35n4.5

Russell-Bowie, D., Roche, L., \& Marsh, H. (1995). Wow! I can do music! A study in selfconcept of student teachers in relation to various subject areas. In J. Southcott (Ed.), Australian Music Education Lecturers conference (pp. 95-106). Melbourne: Australian Music Education Lecturers Association.

Ryan, A. (2005). Teacher development and educational change: empowerment through structured reflection. Irish Educational Studies, 24(2-3), 179-198. https://doi. org/10.1080/03323310500435463

San, I. (1998). The Development of Drama in Education in Turkey. Research in Drama Education: The Journal of Applied Theatre and Performance, 3(1), 96-99. https://doi. org/10.1080/1356978980030110

Sternberg, P. (1998). Theatre for conflict resolution: In the classroom and beyond. Portsmouth, $\mathrm{NH}$ : Heinemann.

Stinson, M. (2009)."Drama is like reversing everything": intervention research as teacher professional development. Research in Drama Education, 14(2), 225-243. https://doi. org/10.1080/13569780902868820

Turković, V. (1999). Obrazovanje za kreativnost putem umjetnosti. Napredak, 3, 356-368.

Upitis, R., Smithrim, K., Patteson, A., \& Meban, M. (2001). The effects of an enriched elementary arts education program on teacher development, artist practices and student achievement: baseline student achievement and teacher data from six Canadian sites. International Journal of Education and the Arts, 2(8). Retrieved from http://www.ijea.org/ $\underline{\mathrm{v} 2 \mathrm{n} 8 /}$ 
Villadsen, A. (2012). The use of role-play and drama in interprofessional education: an evaluation of a workshop with students of social work, midwifery, early years and medicine. Social Work Education, 31(19), 75-89. https://doi.org/10.1080/02615479.201 $\underline{0.547186}$

Waldschmidt, E. D. (1998). Bilingual teachers learning about creative drama: a transformative process. Youth Theatre Journal, 12(1), 96-108. https://doi.org/10.1080/08929092.1998.10 $\underline{012499}$

Walker, E. M., McFadden, L. B., Tabone, C., \& Finkelstein, M. (2011). Contribution of dramabased strategies.Youth Theatre Journal, 25(1), 3-15. https://doi.org/10.1080/08929092.20 $\underline{11.569471}$

Welch, A. (1995). The self-efficacy of primary teachers in art education. Issues in Educational Research, 5, 71-84.

Wright, J. P. (2006). Drama education and development of self: myth or reality? Social Psychology of Education, 9, 43-65. https://doi.org/10.1007/s11218-005-4791-y

Wright, P. (1999). The Thought of Doing Drama Scares Me to Death. Research in Drama Education, 4,227-237. https://doi.org/10.1080/1356978990040206

\section{Zrinka Vukojević}

University of Zagreb, Faculty of Teacher Education

Savska cesta 77, 10000 Zagreb, Croatia

zrinka.rogulj@ufzg.hr 


\section{Mišljenja budućih učitelja primarnog obrazovanja o primjeni dramskog odgoja u nastavi}

\section{Sažetak}

U radu su prikazani rezultati istraživanja kojem je cilj bio ispitati povezanost između osjećaja kompetentnosti budućih učitelja primarnog obrazovanja prema dramskom odgoju $i$ njihovih mišljenja o važnosti i primjeni dramskog odgoja u nastavi. Istraživanje je provedeno na uzorku od $N=225$ studenata. U istraživanju su sudjelovali studenti Učiteljskog fakulteta u Zagrebu (N=95) s odsjekom u Čakovcu $(N=69)$ i Petrinji (N=26), kao i Filozofskog fakulteta u Splitu, učiteljski smjer ( $N=35)$. Rezultati istraživanja pokazuju da su studenti skloni dramskom odgoju, međutim samo $15 \%$ ispitanika se smatra kompetentnima za primjenu dramskog odgoja u nastavi.

Ključne riječi: dramski odgoj; kompetencije; studenti primarnog obrazovanja.

\section{Uvod}

Teorijska razmatranja pokazuju da je umjetnost predmet zanimanja mnogih znanstvenika i stručnjaka koji se bave unapređenjem procesa odgoja i obrazovanja. Na nju se obično gleda kao na sredstvo promicanja učenikovih kreativnih sposobnosti i stvaranja. Umjetnost pomaže učeniku da razvije sposobnost preuzimanja inicijative, emocionalnu inteligenciju, maštu, kritičko i analitičko mišljenje. Umjetničkim obrazovanjem utječemo na cjelokupan razvoj pojedinca, a njegovi sadržaji doprinose boljem snalaženju u suvremenom svijetu i pripremi za budućnost u kojoj se traži fleksibilnost, brzo donošenje odluka i rješavanje problema (Turković, 1999). Prema Alter, Hays, i O’Hara (2009) učitelji primarnog obrazovanja neophodni su poučavatelji nastavnih predmeta koji uključuju znanja iz psihologije, pedagogije, filozofije, književnosti, lingvistike, informatike i prirodnih znanosti. Specifičnim dijelom struke stječu se znanja i vještine iz umjetničkih područja. Sve to za učitelja predstavlja veliku odgovornost te je povezano s kvalitetom poučavanja i ovisi o učiteljevu samopouzdanju i kompetencijama u procesu poučavanja. Prema istraživanju Ng, Nicholas, i Williams (2010) učitelji posjeduju različita znanja, iskustva i vještine koji 
su potrebni za poučavanje različitih nastavnih predmeta. Jacobs (2008) naglašava kako zbog manjka znanja, iskustva i samopouzdanja u umjetničkim područjima učitelji najčešće oblikuju negativan stav o umjetnosti, što se reflektira na implementaciju umjetničkih sadržaja u radu s učenicima. Kvaliteta i kvantiteta poučavanja umjetničkih sadržaja očituje se u odgojnoj i obrazovnoj pozadini i samopouzdanju budućih učitelja primarnog obrazovanja. S obzirom na to da kvalitetno planiranje i provođenje odgojno-obrazovnog procesa koji uključuje i umjetnička područja ovisi o učitelju, cilj ovog istraživanja bio je ispitati mišljenja budućih učitelja primarnog obrazovanja o primjeni dramskog odgoja u nastavi.

\section{Važnost dramske umjetnosti u odgoju i obrazovanju}

Dramska umjetnost kao posebno umjetničko polje prv je put upisana u hrvatski Nacionalni okvirni kurikulum za predškolski odgoj i obrazovanje te opće obvezno i srednjoškolsko obrazovanje (NOK, 2011). Istraživanja su pokazala da dramska umjetnost utječe na razvoj djetetovih jezičnih sposobnosti i empatije (Adomat, 2012; Anderson, 2012; Barnes, 2014; Holland, 2009) te povećava učenikovu motivaciju i angažiranost za učenje (Martin i drugi, 2013). U hrvatskom kurikulu iz ishoda učenja vidljivo je nastojanje da se dramska umjetnost, unutar školskih i predmetnih kurikula, prepozna ne samo kao sadržaj pojedinih nastavnih predmeta (npr. nastave književnosti) već kao nastavna metoda i oblik iskustvenog učenja i poučavanja primjenjiv u različitim odgojno-obrazovnim područjima i za različite odgojnoobrazovne teme (Krušić, 2014). U posljednjih deset godina brojna istraživanja (Drama Improves Lisbon Key Competences in Education Consortium, 2011; Mclauchlan i Winters, 2014; Villadsen, 2012; Walker i drugi, 2011; Wright, 2006) ukazuju na važnost integriranja dramske umjetnosti u odgojno-obrazovni sustav. $U$ anglosaksonskim zemljama drama se koristi kao suvremena metoda učenja i poučavanja. Najčešće se definira kao nastavna metoda s pomoću koje se stvara fiktivno okruženje s ciljem da pojedinac preuzme ulogu te razvija svoja iskustva, znanja, osjećaje i vještine (Ekeberg, Lepp, i Dahlberg, 2004; San, 1998; Sternberg, 1998). Iako hrvatska odgojno-obrazovna politika prepoznaje obrazovne, kulturne i socijalne prednosti dramske umjetnosti u odgojno-obrazovnom procesu, njezina implementacija nedovoljno se probija u svakodnevni odgojno-obrazovni rad. Razlog je tomu što učitelji marginaliziraju predmete kojima nisu skloni i iz kojih ne posjeduju znanja i vještine (Alter, Hays, i O'Hara, 2009). Novija teorijska razmatranja pozivaju na promjene u poučavanju budućih učitelja primarnog obrazovanja. Naglašavaju da učitelj treba biti inovator u svom odgojno-obrazovnom radu, a da bi to ostvario, potrebno je implementirati kreativne i maštovite metode koje će njegovo poučavanje učiniti zanimljivim, relevantnim i privlačnim. Primjena takvih metoda i pristupa radu zadovoljit će djetetovu potrebu za igrom, maštanjem i stvaralaštvom. Implementiranje drame u odgojno-obrazovni rad s učenicima predstavlja interpretativan proces s ciljem boljeg razumijevanja stvarnosti (Laakso, 2005). Prema Duma i Silverstein (2008) dramski 
odgoj potiče motivaciju, razvija višestruke inteligencije i potiče različite stilove učenja. Položaj učitelja i učenika u takvom obliku rada učeniku otvara mogućnost slobodnog izražavanja osjećaja, misli i stavova te donošenja odluka (McNaughton, 2006). Na taj se način gubi učiteljeva autoritativna maska i potiče se interakcija s ciljem raspravljanja i pregovaranja s učenicima kao i njihova aktivnog uključivanja u odgojno-obrazovni proces (Upitis i drugi, 2001). U početku su se učitelji ustručavali primjenjivati dramu kao metodu poučavanja zbog nedostatka znanja (Fynn, 1997) ili zbog vremenskog ograničenja (Stinson, 2009). Međutim, s dramskim iskustvom, znanjem i vještinama počeli su kreativnost implementirati na učinkovitiji način i dramsko iskustvo primjenjivati u nastavnim predmetima za različite odgojno-obrazovne svrhe (Oreck, 2006). Uz prikladne dramske metode učitelji se mogu suočiti s problemima i izazovima u svom profesionalnom radu, postati svjesni poetsko-estetske dimenzije dramske umjetnosti (Kerry-Moran i Meyer, 2009), razvijati vokabular, unaprijediti svoje nastavne metode te steći znanja iz različitih područja. Istraživanja pokazuju da implementiranjem drame u odgojno-obrazovni proces učitelji postaju predstavnici obrazovne promjene (Ryan, 2005). Pružajući podršku, motivaciju, stručnost, znanje i vještine u takvim oblicima rada (Oreck, 2006), oni omogućuju učenicima kvalitetnu životnu praksu (Raphael i O’ Mara, 2002). Prema Waldschmidt (1998) učitelji ističu da integriranje drame u nastavu ne bi bilo moguće bez učenja na vlastitoj koži i prethodno stečenog znanja.

\section{Dramski odgoj u visokoškolskom obrazovanju}

Profil učitelja koji se obrazuje na visokoškolskim institucijama temelji se na kvalitetnom pedagoško-psihološkom, metodičkom i stručnom obrazovanju, što učiteljima omogućuje kreativnost, snalažljivost i fleksibilnost u odgojno-obrazovnom procesu. Programi na učiteljskim fakultetima trebali bi studentima pružiti znanja, vještine i iskustva prijeko potrebna za njihov uspješan rad. Najnovija teorijska i praktična istraživanja o integriranju dramskog odgoja u nastavu dokazuju da drama potiče razvoj kreativnih i intelektualnih mogućnosti djeteta. U istraživanju Lummis i drugi (2015) ispitivala su se mišljenja i iskustva budućih učitelja o dramskom odgoju. Rezultati istraživanja pokazali su da oni studenti koji su u djetinjstvu i tijekom osnovnoškolskog obrazovanja pohađali dramske studije, odlazili u kazalište te su ih učitelji poučavali primjenom dramskih metoda, pokazuju veću sklonost prema dramskom odgoju, a samim time ističu njegovu važnost u odgojno-obrazovnom procesu. U istraživanju Russell-Bowie i drugi (1995) pokazalo se da će, ako studenti primarnog obrazovanja imaju veće predznanje iz dramskog odgoja te su tijekom fakultetskog obrazovanja bili uključeni u dramske odgojno-obrazovne aktivnosti, to uvelike pridonijeti njihovu samopouzdanju i kompetentnosti u primjeni metoda i tehnika dramskog odgoja u nastavi. Prema Russell-Bowie (2010) naglasak na razvoju znanja, sposobnosti, stavova i vještina iz dramskog odgoja rezultirat će većom kompetencijom studenata, a samim time i sklonosti prema dramskom odgoju. Akin 
(2014) ističe da budući učitelji pokazuju veliku sklonost prema dramskom odgoju jer smatraju da će se njegovom implementacijom u nastavi olakšati rad s učenicima i nastavu učiniti zanimljivijom i zabavnijom. $S$ druge strane, prema istraživanju Wright (1999), većina studenata primarnog obrazovanja pri pohađanju umjetničkih kolegija pokazuje tremu i strah ako moraju sudjelovati u umjetničkim aktivnostima. Alter i drugi (2009) naglašavaju da trema uvelike utječe na kompetentnost i uspješnost u poučavanju umjetničkih predmeta. Pokazalo se da oni studenti koji imaju višu samoprocjenu treme, smatraju da bi dramski odgoj trebali poučavati specijalizirani učitelji, a ne učitelji primarnog obrazovanja. U skladu s navedenim istraživanjima cilj ovog istraživanja bio je ispitati mišljenja studenata - budućih učitelja primarnog obrazovanja u Zagrebu, Splitu, Čakovcu i Petrinji o vlastitoj kompetentnosti i sklonosti prema dramskom odgoju u odgojno-obrazovnom procesu.

\section{Metodologija}

\section{Cilj, problemi i hipoteze istraživanja}

Cilj istraživanja bio je ispitati povezanost između samoprocjena kompetentnosti budućih učitelja primarnog obrazovanja u području dramskog odgoja, njihovih mišljenja o važnosti dramskog odgoja u nastavi i sklonosti učitelja primjeni dramskog odgoja. Polazimo od opće ideje da će oni studenti koji se smatraju kompetentnijima, u većoj mjeri vjerovati da je primjena dramskog odgoja u nastavi važna i da učitelji vole poučavati primjenom dramskog odgoja. Također će biti skloniji mišljenju da oni, a ne specijalizirani učitelji, trebaju poučavati primjenom dramskog odgoja u nastavi. U skladu s tako formuliranim ciljem definirani su sljedeći problemi i postavljene hipoteze:

1. Konstruirati upitnik za samoprocjenu kompetentnosti u dramskom odgoju kod budućih učitelja primarnog obrazovanja.

2. Ispitati povezanost između samoprocjena kompetentnosti i mišljenja o važnosti dramskog odgoja u nastavi.

3. Ispitati povezanost između samoprocjena kompetentnosti i mišljenja o sklonosti učitelja prema primjeni dramskog odgoja.

4. Ispitati razlike u samoprocjenama kompetentnosti između studenata koji misle da dramski odgoj trebaju primjenjivati specijalizirani učitelji, učitelji razredne nastave ili jedni i drugi podjednako.

H2.1. Očekuje se pozitivna povezanost između samoprocjena kompetentnosti i procjena važnosti dramskog odgoja u nastavi.

H3.1. Očekuje se pozitivna povezanost između samoprocjena kompetentnosti i procjena studenata da učitelji vole primjenjivati dramski odgoj.

H4.1. Očekuje se da će studenti koji misle da dramski odgoj trebaju primjenjivati učitelji primarnog obrazovanja, sebe procjenjivati kompetentnijima u dramskom odgoju od studenata koji misle da to trebaju primjenjivati specijalizirani učitelji ili jedni i drugi učitelji podjednako. 


\section{Uzorak ispitanika}

Istraživanje je provedeno u studenom akademske godine 2016./2017. Upitnik je proveden na uzorku od 225 studenata. Ispitanici su bili studenti učiteljskog studija Učiteljskog fakulteta u Zagrebu (N=95), odsjeka u Čakovcu (N=69) i Petrinji (N=26) i Filozofskog fakulteta u Splitu, učiteljski smjer $(\mathrm{N}=35)$. Upitnik su ispunjavali studenti pete godine učiteljskog studija $(\mathrm{N}=225)$. Ispitanicima je objašnjena svrha provođenja istraživanja, zajamčena im je anonimnost te su zamoljeni da iskreno odgovaraju na pitanja. Također, sudionici su u svakom trenutku mogli odustati od sudjelovanja $u$ istraživanju.

\section{Instrumenti}

Ovo istraživanje dio je većeg istraživanja u kojem se koristio upitnik o stavovima budućih učitelja primarnog obrazovanja prema kreativnim umjetnostima (Creative Arts: Students' Attitudes: National and Oversease Associates, prema Russell-Bowie, 2013).

Iz navedenog upitnika odabrane su tvrdnje relevantne za probleme ovog istraživanja. $\mathrm{Na}$ temelju tih tvrdnji konstruirana su dva upitnika: upitnik za samoprocjenu kompetentnosti u dramskom odgoju i upitnik za ispitivanje mišljenja o važnosti dramskog odgoja u nastavi.

\section{Samoprocjena kompetentnosti u dramskom odgoju}

Iz prethodno navedenog upitnika odabrane su tvrdnje koje su se odnosile na iskustvo sudionika u dramskom odgoju (U slobodno vrijeme sudjelujem u aktivnostima iz područja dramskog odgoja), znanja i vještine u području dramskog odgoja (Smatram da posjedujem znanja i kompetencije za primjenu dramskog odgoja), sklonost dramskom odgoju (Voljela/volio bih da ima više izbornih kolegija o dramskom odgoju) i tremu prilikom izvođenja dramskog odgoja (Neugodno mi je kad pred učenicima moram glumiti). Početni upitnik imao je 22 tvrdnje koje su se odnosile na različite osobine budućih učitelja važne za primjenu dramskog odgoja u nastavi. Nakon faktorske analize zadržano je 18 tvrdnji. Sudionici su procjenjivali svaku tvrdnju na skali od pet stupnjeva ( 1 - uopće se ne slažem do 5 - u potpunosti se slažem). Faktorska struktura upitnika prikazana je u dijelu o rezultatima istraživanja.

\section{Mišljenje o važnosti dramskog odgoja u nastavi}

Iz navedenog upitnika odabrane su i 4 tvrdnje koje su se odnosile na mišljenje studenata o važnosti dramskog odgoja u školi:

U osnovnoškolskom obrazovanju trebala bi se dati veća važnost dramskom radu s djecom.

Mislim da je dramski odgoj nedovoljno zastupljen u primarnom obrazovanju.

Učenicima je potrebno obrazovanje primjenom metoda i tehnika dramskog odgoja. Dramski odgoj jednako je važan kao i ostali nastavni predmeti u primarnom obrazovanju. 
Sudionici su procjenjivali svaku tvrdnju na skali od pet stupnjeva ( 1 - uopće se ne slažem do 5 - u potpunosti se slažem). Faktorska analiza metodom glavnih komponenti rezultirala je jednim faktorom koji je objašnjavao $48,66 \%$ varijance. Cronbachov a koeficijent pouzdanosti iznosio je ,71, što je prihvatljiva vrijednost. Ukupan rezultat definiran je kao prosječni rezultat na navedenim tvrdnjama. Veći rezultat ukazuje na to da učitelji pridaju veću važnost dramskom odgoju u osnovnoj školi.

\section{Sklonost učitelja prema primjeni dramskog odgoja}

Procjena sklonosti učitelja prema primjeni dramskog odgoja mjerena je jednom tvrdnjom: Mislim da učitelji primarnog obrazovanja vole primjenjivati dramski odgoj. Sudionici su procjenjivali tu tvrdnju na skali od pet stupnjeva ( 1 - uopće se ne slažem do 5 - u potpunosti se slažem).

\section{Mišljenje o tome tko treba primjenjivati dramski odgoj u primarnom obrazovanju}

Sudionici su procjenjivali dvije tvrdnje na skali od pet stupnjeva (1 - uopće se ne slažem do 5 - u potpunosti se slažem).

U osnovnoškolskom obrazovanju specijalizirani nastavnici trebali bi primjenjivati dramski odgoj.

U osnovnoškolskom obrazovanju učitelji primarnog obrazovanja trebali bi primjenjivati dramski odgoj.

$\mathrm{Na}$ temelju tih procjena sudionici su podijeljeni u tri skupine: oni koji su prednost dali učiteljima primarnog obrazovanja, oni koji su prednost dali specijaliziranim učiteljima i oni koji procjenjuju da i jedni i i drugi mogu primjenjivati dramski odgoj.

\section{Obrada podataka i upotrijebljene statističke metode}

Za provjeru faktorske strukture upitnika provedena je eksploratorna faktorska analiza metodom glavnih komponenti. Za određivanje povezanosti između samoprocjena kompetentnosti u dramskom odgoju i mišljenja o važnosti dramskog odgoja u nastavi i sklonosti učitelja prema primjenjivanju dramskog odgoja provedene su regresijske analize. Za testiranje razlika u samoprocjenama kompetentnosti između tri skupine studenata koji imaju različito mišljenje o tome tko treba primjenjivati dramski odgoj u osnovnoj školi koristile su se jednosmjerne analize varijance.

\section{Rezultati i rasprava}

\section{Provjera konstruktne valjanosti upitnika za samoprocjenu kompetentnosti u dramskom odgoju budućih učitelja primarnog obrazovanja.}

Sa svrhom provjere faktorske strukture provedena je eksploratorna faktorska analiza metodom glavnih komponenti. Inicijalna faktorska analiza s 21 česticom rezultirala je s pet faktora koji su objašnjavali $64,791 \%$ ukupne varijance. Kako sadržaj faktora nije 
bio smisleno interpretabilan, na temelju Scree testa ponovljena je faktorska analiza s oblimin rotacijom na tri faktora. Četiri tvrdnje remetile su faktorsku strukturu zbog niskih opterećenja (nižih od ,30) i/ili opterećenja na više faktora. Nakon uklanjanja te 4 tvrdnje (U slobodno vrijeme sudjelujem u aktivnostima iz područja dramskog odgoja, Članovi moje obitelji uključeni su u aktivnosti iz područja dramskog odgoja, U osnovnoj i srednjoj školi moje izvannastavne aktivnosti bile su iz područja dramskog odgoja i Mislim da je potrebno biti glumac da bih bio/bila kompetentna za poučavanje dramskog odgoja) ponovljena je faktorska analiza metodom glavnih komponenti s oblimin rotacijom na 17 čestica. Kaiser-Meyer-Olkin testom $(\mathrm{KMO}=, 847)$ i Bartlettovim testom sfericiteta $\left(\chi^{2}=1510,691 ; p=, 000\right)$ utvrđeno je da su podatci prikladni za faktorizaciju. Dobivena trofaktorska struktura bila je interpretabilna, a tri faktora zajedno objašnjavala su 51,687\% ukupne varijance (Tablica 1). Prvi faktor može se nazvati faktorom Znanja i vještine o dramskom odgoju i objašnjava $31,672 \%$ varijance. Drugi faktor može se nazvati faktorom Sklonost dramskom odgoju i nakon rotacije objašnjava 11,641\% varijance. Treći faktor nazvan je Trema i objašnjava $8,375 \%$ varijance.

Cronbachov a koeficijent pouzdanosti podljestvice Znanja i vještine o dramskom odgoju koju čini 9 tvrdnji iznosi ,807 podljestvice, Sklonost dramskom odgoju koju čini 5 tvrdnji ,790, a podljestvice Trema koju čine 3 tvrdnje ,809, što su prihvatljive vrijednosti.

\section{Tablica 1}

Tvrdnje Osjećam se nedoraslo na kolegijima iz područja dramskog odgoja i Nisam zainteresiran za glumu rekodirane su. Ukupan rezultat na svakoj podljestvici definiran je kao prosječan rezultat na tvrdnjama koje ulaze u tu podljestvicu. Viši rezultat na podljestvici Znanja i vještine odražava bolju samoprocjenu znanja i vještina u dramskom odgoju, a viši rezultat na skali Sklonost dramskom odgoju odražava veću sklonost prema toj umjetnosti. Viši rezultat na podljestvici Treme ukazuje na veću nelagodu pri izvođenju dramskih metoda i tehnika pred drugima.

\section{Deskriptivni pokazatelji}

Tablica 2

Za sve varijable izračunate su vrijednosti, asimetričnosti i spljoštenosti. Vrijednosti za asimetričnost kretale su se od -,048 do -,728, a za spljoštenost od -,435 do -,948 što opravdava korištenje parametrijskih statističkih postupaka.

Najveću procjenu sudionici daju za svoju sklonost prema dramskom odgoju $(\mathrm{M}=3,67, \mathrm{SD}=0,88)$, nakon čega slijedi procjena za znanja i vještine o dramskom odgoju ( $\mathrm{M}=3,26, \mathrm{SD}=0,77)$. Obje procjene su nešto iznadprosječne. Kad je u pitanju trema, studenti pokazuju nešto ispodprosječan rezultat $(\mathrm{M}=2,78 ; \mathrm{SD}=2,78)$. Također, $\mathrm{u}$ iznadprosječnoj mjeri pridaju važnost dramskom odgoju u nastavi $(\mathrm{M}=4,22$; $\mathrm{SD}=0,61$ ), a nešto iznadprosječno procjenjuju da učitelji vole primjenjivati dramski odgoj $(\mathrm{M}=3,68 ; \mathrm{SD}=1,06)$. 
Korelacije između ispitivanih varijabli bile su u očekivanom smjeru. Korelacija između samoprocjena znanja i vještina i sklonosti prema dramskom odgoju je pozitivna $(\mathrm{r}=, 41)$, a obje su korelacije tih dimenzija s podljestvicom treme negativne $(\mathrm{r}=-, 42 \mathrm{i} \mathrm{r}=-, 44)$. Također, samoprocjene znanja i vještina i sklonosti dramskom odgoju u pozitivnoj su korelaciji s procjenama važnosti dramskog odgoja $(r=, 26$ i $r=, 46)$ i procjenom sklonosti učitelja prema primjenjivanju dramskog odgoja $(\mathrm{r}=, 41 \mathrm{i} \mathrm{r}=, 34)$. Suprotno tome, trema je bila u negativnoj korelaciji s tim varijablama (r=-,25 i r=-,27).

Rezultati istraživanja pokazuju da su studenti - budući učitelji primarnog obrazovanja skloni dramskom odgoju. Kod procjena znanja i vještina samo 15\% studenata - budućih učitelja dalo je procjenu 4 i više, što znači da se uglavnom ili u potpunosti slažu da su kompetentni za primjenu dramskog odgoja u nastavi. Trema se nije pokazala značajnim prediktorom za ispitivane varijable.

\section{Povezanost između samoprocjena kompetentnosti i mišljenja o važnosti dramskog odgoja u nastavi i sklonosti učitelja poučavanju dramskog odgoja}

Za određivanje povezanosti između samoprocjena kompetentnosti i važnosti dramskog odgoja u nastavi provedene su dvije regresijske analize, zasebno za svaki kriterij (Tablica 3).

Tablica 3

Regresijske analize su pokazale da je sklonost dramskom odgoju jedini značajan prediktor važnosti koju studenti pridaju dramskom odgoju u nastavi $(\beta=, 52)$. Što studenti, prema vlastitoj procjeni, imaju veću sklonost prema dramskom odgoju, to u većoj mjeri ističu njegovu važnost u nastavi. Kad je u pitanju mišljenje studenata o tome koliko učitelji primarnog obrazovanja vole primjenjivati dramski odgoj, značajni su prediktori znanje i vještine o dramskom odgoju $(\beta=, 31)$, ali i sklonost dramskom odgoju $(\beta=, 20)$. Što studenti, prema vlastitoj procjeni, imaju više znanja i vještina o dramskom odgoju, i što su skloniji dramskom odgoju, to u većoj mjeri vjeruju da učitelji vole primjenjivati dramski odgoj. Trema se nije pokazala značajnim prediktorom ni za jednu kriterijsku varijablu. Rezultati istraživanja pokazuju da oni studenti - budući učitelji koji su tijekom svog života upoznati sa sadržajima i aktivnostima dramskog odgoja, pokazuju veću sklonost prema dramskom odgoju, a samim time $i$ ističu njegovu važnost u odgojno-obrazovnom procesu. Znanja i vještine o dramskom odgoju najznačajniji su prediktor mišljenja da učitelji primarnog obrazovanja vole primjenjivati dramski odgoj. Sklonost dramskom odgoju značajan je prediktor, ali u manjoj mjeri. Ti rezultati djelomično potvrđuju prve dvije hipoteze.

\section{Samoprocjene kompetentnosti i mišljenje o tome tko treba primjenjivati dramski odgoj}

Također su ispitana mišljenja studenta o tome tko bi trebao primjenjivati metode i aktivnosti iz područja dramskog odgoja. Sudionici su podijeljeni u tri skupine. Prvu 
skupinu čine oni koji prednost daju učiteljima primarnog obrazovanja $(\mathrm{N}=65,28,1 \%)$, drugu skupinu oni koji misle da bi trebali primjenjivati specijalizirani učitelji ( $\mathrm{N}=79$, $35,1 \%)$ a treću skupinu sudionici koji misle da mogu primjenjivati i jedni i drugi učitelji ( $\mathrm{N}=81,36 \%)$. Kako bi se testirale razlike u samoprocjenama kompetentnosti između tih triju skupina studenata, provedene su tri jednosmjerne analize varijance (Tablica 4). Prije provođenja analize testirana je homogenost varijance Levenovim testom koji je potvrdio homogenost varijanci.

\section{Tablica 4}

Sva tri F omjera bila su značajna, što znači da se tri skupine studenata međusobno značajno razlikuju po rezultatima na sve tri podljestvice samoprocjena kompetentnosti. Naknadno testiranje razlika između aritmetičkih sredina Tukey testom pokazalo je da kad su u pitanju samoprocjene znanja i vještina studenata koji misle da dramski odgoj trebaju primjenjivati specijalizirani učitelji, svoje znanje i vještine procjenjuju značajno lošijim od studenata koji misle da dramski odgoj trebaju primjenjivati učitelji primarnog obrazovanja $(\mathrm{p}=, 001)$ ili i jedni i drugi učitelji podjednako $(\mathrm{p}=, 000)$. Kad je u pitanju samoprocjena sklonosti prema dramskom odgoju, studenti koji misle da dramski odgoj trebaju primjenjivati specijalizirani učitelji, svoju sklonost dramskom odgoju procjenjuju značajno manjom od studenata koji misle da dramski odgoj trebaju primjenjivati i jedni i drugi učitelji $(\mathrm{p}=, 027)$. Studenti koji misle da dramski odgoj trebaju primjenjivati učitelji primarnog obrazovanja, imaju značajno niže samoprocjene treme od studenata koji misle da dramski odgoj trebaju primjenjivati specijalizirani učitelji ( $\mathrm{p}=, 001)$ ili i jedni i drugi učitelji $(\mathrm{p}=, 026)$. Analizom kovarijance utvrđeno je da su oni studenti - budući učitelji, koji se procjenjuju kompetentnijima u dramskom odgoju, skloniji misliti da dramski odgoj trebaju primjenjivati učitelji primarnog obrazovanja, ali i specijalizirani učitelji. Rezultati pokazuju da studenti budući učitelji koji procjenjuju da imaju manje znanja i vještina iz područja dramskog odgoja, smatraju da bi dramski odgoj trebali primjenjivati specijalizirani učitelji. Sklonost dramskom odgoju značajan je prediktor mišljenja da bi dramski odgoj trebali primjenjivati učitelji primarnog obrazovanja, ali i specijalizirani učitelji. S druge strane, oni studenti - budući učitelji koji imaju manje sklonosti prema dramskom odgoju, smatraju da bi dramski odgoj trebali primjenjivati isljučivo specijalizirani učitelji. Rezultati istraživanja u skladu su s istraživanjem Wright (1999) gdje se pokazalo da oni studenti - budući učitelji koji imaju višu samoprocjenu treme, smatraju da bi dramski odgoj trebali primjenjivati specijalizirani učitelji, za razliku od onih studenta - budućih učitelja koji imaju manju samoprocjenu treme te su mišljenja da dramski odgoj trebaju primjenjivati učitelji primarnog obrazovanja i specijalizirani učitelji. Na temelju tih podataka može se zaključiti da znanja, vještine i sklonosti prema dramskom odgoju pridonose mišljenju da dramski odgoj trebaju primjenjivati i učitelji primarnog obrazovanja i specijalizirani učitelji. 


\section{Zaključak}

Rezultati provedenog istraživanja pokazali su da su budući učitelji primarnog obrazovanja skloni dramskom odgoju, što dokazuje njihovu svjesnost o prednostima koje dramski odgoj donosi svojom primjenom u nastavi. Međutim, samo se $15 \%$ studenata primarnog obrazovanja smatra kompetentnima za primjenu dramskog odgoja u nastavi. Također, rezultati pokazuju da oni studenti - budući učitelji primarnog obrazovanja koji su tijekom svog odgojno-obrazovnog razvoja upoznati s metodama i tehnikama dramskog odgojnog rada, pokazuju veću sklonost prema dramskom odgoju, a samim time ističu važnost njegove implementacije u odgojnoobrazovni proces. Studenti - budući učitelji primarnog obrazovanja mišljenja su da su potrebna znanja i vještine o dramskom odgoju razlog zašto učitelji primarnog obrazovanja vole primjenjivati dramski odgoj. Naime, sklonost se također pokazala kao prediktor, ali u manjoj mjeri. To je ujedno i pokazatelj da je potrebno razvijati sposobnosti i vještine budućih učitelja na učiteljskim studijima za primjenu dramskog odgoja u nastavi kako bi stečene kompetencije o dramskom odgoju bile što kvalitetnije i primjenjivije u odgojno-obrazovnom radu budućih učitelja. Također, rezultati pokazuju da oni studenti koji procjenjuju da posjeduju znanja, vještine i sklonosti o dramskom odgoju, smatraju da dramski odgoj trebaju primjenjivati učitelji primarnog obrazovanja, ali i specijalizirani učitelji. A da oni studenti koji su manje kompetentni i imaju manje sklonosti prema dramskom odgoju, prednost daju specijaliziranim učiteljima. Na temelju analize dobivenih rezultata, a sa svrhom stjecanja odgovarajućih kompetencija za primjenu dramskog odgoja u odgojno-obrazovnom procesu, dolazimo do zaključka da je na učiteljskim studijima potrebno razmotriti, preispitati i definirati ključne kompetencije koje studenti stječu tijekom svog formalnog obrazovanja iz područja dramskog odgoja, a koje su im potrebne za organizaciju suvremene nastave. 